\title{
The Islamic Education's Development Among the Malay's Society in the Early of 20th Century and the Contribution of Kaum Muda
}

\author{
Ermy Azziaty Rozali \\ Department of Arabic Studies and Islamic Civilization \\ Faculty of Islamic Studies \\ Universiti Kebangssaan Malaysia \\ 43600, Bangi \\ ermy@ukm.my
}

\begin{abstract}
Aspects of education are the central of development for the community, race and nation. Islamic education for the Malay started as early as the arrival of the Islam itself. The institutions of pondok and madrasah are the pulse of the intellectual and scientific development for the Malay community. The purpose of this proposal is to study the role of Kaum Muda in the reformation of the education for the Malay society in the early of 20th century. The figures of Islam, such as Sayid Sheikh al-Hadi, Sheikh Tahir Jalaluddin and Sheikh Abdullah Maghribi play an important role in the development of the education for the Malay community in the early of 20th century. The education system which is more modern is being introduced to the madrasah by offering the non-religious co-curriculum as well as stressing on the religious co-curriculum. Malays are advised to pay more attention to the education aspects, especially to those youth generation so that they manage to compete with the Malay community. Due to this concern, this study found the renewal supported by Kaum Muda in the Islamic education of the Malay brings positive developments in the education of the Malays.
\end{abstract} Muda

Keywords-component; islamic education; malay society; Kaum

\section{INTRODUCTION}

The development of Islamic education for the Malay started along with the arrival of Islam. It can be clearly shown by the activity of teaching Quran and theology at home, surau and mosque. The development of the Islamic education is then increased rapidly through the institutions of pondok and madrasah which is then gaining responses by the students from every age and community. Malay's early education stressing on the al-Quran's lesson and the basic knowledge such as reading, writing and counting.

In the 19th century, most of the Malay's children get their education in Patani and then to the West Asia, such as Egypt and the Hijaz to further their study. Some of them directly went to the Middle East and soon after finish studying there, this group of people will play their role by establishing the institutions to provide the education for the local people. This is where the education's system for the pondok begins when both local and foreign students come all the way to learn and stay at the pondok which are built in the area of Tuan Guru's house. This kind of formal education system is very popular in the North state of the peninsula Tanah Melayu as well as in the East Coast such as in Kedah, Kelantan and Terengganu. However, these kinds of institutions are hardly found in Johor, Melaka, Sabah and Sarawak [1].

The theologian plays an important role in the education system through the education of pondok which is the basic education for Malay. The first pondok's education's instituition was first built in Patani, Thailand. The awareness on the importance of knowledge starts to grow among the Malay's society. The increase on the numbers of students all over the country result to the formation of the pondok's education system. Pondoks was built in the area of Tuan Guru's house. The education of pondok in Patani affects the formation of the pondok's education in Malaysia. Most of the Islamic books are written by a theologian named Sheikh Daud al-Fatani. Kitab Furu' al-masail wa Usul al-Masail is the example of book translated by him. On 1899, Kelantan, Terengganu, Perlis and Kedah are under the auspices of Siam (Thailand). This kind of relationship in between them provides the facilities to the Malay students to further their study in Patani. Most of the teachers who were the pioneer of the pondok's education in the 18th until the 20th get their first education in Patani before them finally further to Mecca [2].

Madrasah is the formal institution of education in Tanah Melayu. The education of madrasah starts a little bit late, which is on the early 20th century. The existence of madrasah is due to the effort of individual, grouping and Majlis Agama Islam as well as from the government. Early of the development of madrasah is associated with the role of Kaum Muda as well as the influence of the Middle East (Nabir Abdullah 1976). Back then, madrasah was built with the cooperation of the members of the community by gotong-royong as well as the contribution from the material part. On 17 Mac 1906, Madrasah alMasriyyah was buit in Bukit Mertajam, Seberang Perai, Pulau Pinang. This madrasah is found by Haji Salleh Masri [3].

Haji Mohd Masri used the fund of wakaf from the villagers to support the management of Madarasah al-Masriyyah, by emulating Al-Azhar. When this madrasah al-Masriyyah is first 
opened on 17 Mac 1906, 30 students of pacemaker enrolled. Emulating the new system of education in Egypt, the lesson provided at this madrasah is differ from the pondok's system as it offers subject of Malay language, mathematics, geography, logic and the crafting skill. Since the curriculum of this madrasah is based on the education system in Egypt, most of the leavers from the madrasah further their study to the country which will then gain the support from the mudir of Madrasah al-Masriyyah.

This kind of effort was then continued by Sayyid Syeikh alHadi and friends such as Sheikh Tahir Jalaluddin and Haji Abbas bin Mohd Taha who's established the Madrasah al-Iqbal al-Islamiyyah in Singapore on February 4, 1908. This madrasah offers the subject of religious knowledge includes the Bahasa Melayu and English (Syed Alwi al-Hadi 1999). The development of the system of this madrasah can be clearly seen with the establishment of Madrasah Muhammadiyyah Melayu on 1917, at the Building of Majlis Agama Islam Dan Adat Istiadat Melayu Kelantan. Sayyid Sheikh al-Hadi was then established Madrasah al-Masyhur al-Islamiyyah on 1919 in Pulau Pinang [4].

The madrasah established by the individual or the group are known as the sekolah agama rakyat. Due to the different founder thus, there are lots of different system of education between the madrasah in this country. Very single madrasah is lead by a mudir (principal) which is sometimes become the owner of the madrasah. The mudir responsible in the administration with the help of The Board of the madrasah who are from the members of the village, Board of the Wakaf, Nazir or the trusted organization which held the veto power of the finance. The education's organization and the teaching lesson depend on the mudir. As the example, he will be in-charged in determining what kind of subject to be taught as well as the books that will be used as the text books for the madrasah. Most of the madrasah offer the lower education level (primary level) and some of them are secondary.

Take a look on the late of 19th century, between the confusion of the Malays facing two system of education (institutions and English schools), a group of Malay students from the Middle East; especially Egypt came up with a new Islamic thinking, Islah. They are consisting of Sayid Sheikh AlHadi, Sheikh Tahir Jalaluddin Al-Falakiy, Hj. Abbas Mohd Taha and Sheikh Muhammad Salim al-Kalali. This kind of thought is under the influence of the Islam's motion which is pioneered by both Sayid Jamaluddin and Muhammad 'Abduh in Egypt. Due to widening of thought of renewal in Islam, education in Islam experiences the new development. Arabic schools which is known as madrasah was established by an individual or certain group, especially by those people from Islah. There are some madrasah come up from the renovation of pondok's system as the result from the education system introduced by the imperialist. Besides that, more pressure is stressed so that a renewal is made to the education system among the Malays.

\section{THE ROLE OF KAUM MUDA ON THE DEVELOPMENT OF EDUCATION AMONG THE MALAY COMMUNITY}

The education system was introduced to compete with the English school. Its existence maintained the 'Islamic' of Malays especially when they were under the control of British. Most of the people who found or established the madrasah came from Kaum Muda whose manage to study in the Middle East, especially from Egypt. Looking deeper into this topic, there are big differences between both system of madrasah and pondok especially from the learning part. At the madrasah the learning method no longer use the halaqah and catchment studies method or the facilities like class division, timetable and the academic subject [5].

In the context of Tanah Melayu, the motion of renewal of the Kaum Muda started from the south which is Singapore then spreading to West Coast and Kelantan. Syeikh Muhammad Tahir Jalaluddin(1869-1956), Syeikh Muhammad Salim alKalali, Syed Syeikh al- Hadi(1867-1934), Syed Muhammad Aqil and Haji Abbas Mohd Taha are the well-known person from Kaum Muda. All of them united and come up with a magazine, al-Imam (1906-1908). This motion of renewal in Tanah Melayu not only focuses on the religion, but also on social, economy, politics, education and so on. The development of education is influenced by the Kaum Muda which introduced Islah in Tanah Melayu. The leaders of Kaum Muda are Syed Sheikh al-Hadi, Sheikh Mohd Tahir Jalaluddin, Hj Abbas Mohd Taha and Haji Salleh Masri. Kaum Muda then approached their four reform ideas which are;

1. Fight for people's development through the purification movement, understanding and appreciation of religion. They concluded that the decline and backwardness of Muslim not because the religion itself, but the mistakes in understanding and appreciating it.

2. Develop the thinking performance through the ijtihad and eradication of taqlid.

3. Refresh the knowledge through the education reformation of Islam- start the system of schools by combining both modern and west knowledge.

4. Upgrade the status and function of Muslim women.

Ideas are channeled through madrasah educational institutions like the Madrasah al Masyhur and Madrasah alQuran in Pulau Pinang(1914), Madrasah al-hadi in Malacca(1917), Madrasah al-Idrisiyyah in Kuala Kangsar(1922) and Madrasah Zainal Abidin in Terengganu. The education system of Kaum Muda was also been modernized. The institution of madrasah not only maintain the religious subject of tradition like tauhid, tafsir, hadith and so on but also includes the Arabic subjects like nahu, saraf, imla', khat, muhadathah, saraf al-fasahah (literature) and insya'.

The general or basic subject like arithmetic, physics, bahasa melayu, tawarikh and general knowledge were also been taught. Besides having the talk on the subjects and handicraft, outdoor activities such as lecture, debate, nasyeed, writing and sport also been introduced. The technique of teaching also change 
using the blackboard and chalk also the usage of textbooks provided. A special system of test introduced, in which the person who fails in the exam will never promote to the next higher level. The Role of Kaum Muda in the magazine of AlImam did explained how much important the Islamic education is among the Malay especially in the education of madrasah, which is proposing a renewal to the Islamic education system. Due to Kaum Muda, Islamic education system must base on the rule and law and with this rule, any subject of language, Arabic, English and so on which are dependent with the modern subject must be taught.

If viewed, the system of education among Malay experienced the development and modernization due to the role played by Kaum Muda especially with the establishment of Madrasah al-Iqbal al-Islamiyyah in Singapore on 1908. This madrasah offers the subjects of arabic, english, bahasa Melayu, arithmetic, geography, history and writing. One of the answerable team who played the role in establishing this madrasah is Rushdiyyah Club. This Club centered in Kepulauan Riau. One of the objectives for establishing Madrasah al-Iqbal al-Islamiyyah is, to introduce the west knowledge through the religious school. However, despite of discourage support from the community, this madrasah tend to survive for only two years [6].

Madrasah al-Iqbal al-Islamiyyah is administered by Uthman Effendi Rif'at and he also hired three more teachers from Cairo. This academic calendar of this madrasah started on Syawal and run for 10 months. It is consist of 2 semesters, includes the holiday, preparation week and examination. After the establishment of this madrasah, a few more madrasah are been established such as the Madrasah Jam'iyyah alKhairiyyah in Muar, Madrasah al-Masyhur al-Islamiyyah in Pulau Pinang, Madrasah al-Hamidiyyah in Kedah and Madrasah al-Khairiyyah in Kota Bharu, Kelantan [7].

Meanwhile in Kelantan, the educationn of madrasah is supported by the Islamic-like education and no restriction from learning the modern knowledge from the west, as they believed that the knowledge is actually came from Islam. This is means that, the increment of Malays' thinking on both Islamic education and secular is been consistence in the education of madrasah. Even though at the very beginning Islamic education system which is pondok's education system doubt the modern education which is use in Malay education. The establishment of Madrasah Muhammadiah on 1917 is the support to the education field of madrasah in Kelantan. Madrasah Muhammadiah launched the program of education by Majlis Agama dan Adat Istiadat Melayu Kelantan which is established on 1915, with three language of teaching which are, Malay, English and Arabic [8].

Apart from the Madrasah al-Iqbal al-Islamiyyah, Madrasah al-Masyhur in Pulau Pinang also had been established with the cooperation and courage from the community of Arabian. However, the members of madrasah decided not to publish the role of this community as British are against any madrasah established in Pulau Pinang except for English stream. Sayid Sheikh al-Hadi is appointed to be the first mudir of Madrasah al-Masyhur. He got experienced in the administration of Madrasah al-Hadi in Malacca. Arabic language is used as the medium language and most of Arabic books used consisting of fiqh, tafsir, nahu and saraf as well as the Arabic language.

Sayid Sheikh al-Hadi managed to bring the authoritative figure to work in this madrasah such as Sheikh Tahir Jalaluddin, Sheikh Abdullah al-Maghribi and Sheikh Mohamed Radzi. Sayid Sheikh al-Hadi then let go his position as a mudir and replaced by Sheikh Abdullah al-Maghribi. Sheikh Abdullah alGhadamisi also brings the reformation into this madrasah. As a liberal theologian, his thought and ideas are more suitable with the islah stream which is supported by Madrasah al-Masyhur. His tendency can be clearly seen as he is close to any other figure of Islah such as Sayid Sheikh al-Hadi and Syeikh Tahir Jalaluddin [9].

As he lead Madrasah al-Masyhur, he tend to make a few renewal by including a few subject such as tafsir, hadith, fiqh, logic, insya',balaghah and nusus. Sheikh Abdullah also invites a few teachers from both Egypt and Mecca. On that time, there are a few well-known local teacher, Sayid Sheikh al-Hadi and Hafiz Ghulam Sharwar. The leavers of Madrasah al-Masyhur gain the recognition from Al-Azhar University. This university also accepts a few leavers from Madrasah al-Masyhur to further their study in their university in Egypt, Mecca and Iraq.

Madrasah al-Masyhur continuing play the role in giving the education to the community and its students, also involve in the motion of Islah which is developing on the early century of 20th (al-Ikhwan 1927). Between the above figure mentioned, Sheikh Tahir Jalauluddin is a well-known figure in the motion of renewing Islam and studied in al-Azhar, Egypt. He was introduced to the renewal group of Muhammad Abduh. As he return to his hometown, the renewal idea and Islah were still practiced [10].

\section{CONCLUSION}

The development of Malay education in the aspect of religion is widening through the madrasah at that time. In that framework, the equilibrium of both knowledge is learnt by Malay people except for English stream and college which is controlled by British. Development of education in the Malay country is the part of result due to the effort of Kaum Muda in fighting the Malay nation concept in education. The framework is the renewal and development in the Malay education, especially the education of Malays will be increased as well as continuing to the higher level.

\section{ACKNOWLEDGMENT}

The research is funded by the Group of Arabic Culture and Islamic Civilization (UKM DPP -2013-158)

\section{REFERENCES}

[1] Awang Had Salleh. Institusi Pondok di Malaysia. Zainal Kling (ed), Masyarakat Melayu antara Tradisi dan Perubahan (Malay Society : Between Tradition and Changes). Kuala Lumpur: Utusan Publications. 1977.

[2] Abdullah Jusoh. Pengenalan Tamadun Islam di Malaysia (Introduction on Islamic Civilisation in Malaysia). Kuala Lumpur : Dewan Bahasa dan Pustaka. 1990.

[3] Othman bin Bakar. "Haji Salleh Masri Pengasas al-Masriyyah" (Haji Salleh Masri Founder al-Masriyyah) Khoo Kay Kim et.al (eds). Islam 
di Malaysia (Islam in Malaysia). Kuala Lumpur : Persatuan Sejarah Malaysia. 1980.

[4] Abdullah Jusoh. Pengenalan Tamadun Islam di Malaysia (Introduction on Islamic Civilisation in Malaysia). Kuala Lumpur : Dewan Bahasa dan Pustaka. 1990.

[5] Andaya \& Andaya. History of Malaysia. London : Macmillan. 1982.

[6] Syed Alwi al-Hadi. "The Life of My Father" . A.Gordon (ed). The Real Cry of Syed Syakh al-Hady. Kuala Lumpur : Malaysia Sociological Research Institute. 1999.
[7] William Roff. Pondoks, "Madrasah and the Production of Ulama in Malaysia”. Studia Islamika. Vol. 11. No. 4. 2004.

[8] Andaya \& Andaya. History of Malaysia. London : Macmillan. 1982.

[9] Wlliam Roff. Pondoks, "Madrasah and the Production of Ulama in Malaysia”. Studia Islamika. Vol. 11. No. 4. 2004.

[10] Mohd. Radzi Othman \& O.K Rahmat, Gerakan Pembaharuan Islam Satu Kajian di Negeri Perlis dan Hubungkaitnya dengan Malaysia. (A Studies on Islamic Reformation Movement in Perlis State and Its Relation in Malaysia). Pulau Pinang : Penerbit USM. 1999. 